\title{
Arsenic Polluted Groundwater and Its Countermeasures in the Middle Basin of the Ganges, Uttar Pradesh State, India
}

\author{
Yasunori Yano $^{1 *}$, Kenichi Ito ${ }^{1}$, Akihiko Kodama ${ }^{2}$, Koichiro Shiomori ${ }^{3}$, Shigeki Tomomatsu ${ }^{3}$, \\ Mitsuhiro Sezaki ${ }^{3}$, Hiroshi Yokota ${ }^{1}$
}

${ }^{1}$ Center for International Relations, University of Miyazaki, Miyazaki, Japan; ${ }^{2}$ Retec Engineering Inc., Tokyo, Japan; ${ }^{3}$ Faculty of Engineering, University of Miyazaki, Miyazaki, Japan.

Email: *anoya@cc.miyazaki-u.ac.jp

Received June $15^{\text {th }}, 2012$; revised July $2^{\text {nd }}, 2012$; accepted July $31^{\text {st }}, 2012$

\begin{abstract}
The arsenic contamination of groundwater in Uttar Pradesh State was first recognized in 2003 and is now seen at 20 Districts out of 70 Districts. University of Miyazaki has performed the arsenic mitigation project in Bahraich District, severest arsenic-affected one in the 20 Districts, from June 2008 until now, with JICA (Japan International Cooperation Agency). The integrated mitigation, such as the raising awareness of villager, installing of alternative water supply units and healthcare of arsenocosis patients, have been executed at the 2 villages. The symptom of the arsenocosis patients was not so severe, which will be, therefore, improved by drinking arsenic-safe water supplied through arsenic removal units, installed by this project. In this paper, following results is discussed for the situation and mechanism of arsenic contamination of groundwater, objected in connection with the installation of arsenic removal units: 1) Groundwater is almost contaminated with arsenic in deep tubewell (depth: about $30 \mathrm{~m}$ ), but scarcely in shallow tubewell (depth: about $10 \mathrm{~m})$; 2) Arsenic contaminated groundwater is under the reduced condition with the oxidized condition for no-arsenic contaminated groundwater; 3) Arsenic concentration shows almost linear correlation with concentrations of $\mathrm{Fe}^{2+}$ and $\mathrm{NH}_{4}^{+}-\mathrm{N}$; 4) Ground is composed of sand with high arsenic content at around $25 \mathrm{~m}$ depth; 5) Arsenic exists mainly in the phase of reducible fraction or weak acid soluble fraction but no oxidizable fraction in the ground.
\end{abstract}

Keywords: Arsenic; Contamination; Ganges; Groundwater; Soil; Mechanism; Removal

\section{Introduction}

Arsenic contamination of groundwater, in Asia, is seen in the basins of the great rivers, originating in the Himalayan Mountains and the Tibetan Plateau, such as the Ganges River, the Indus River, the Mekong River, the Haw River, and the Yellow River [1], where people depend on the drinking water for groundwater. A thermally altered metamorphic zone in the Higher Himalaya, containing various types of minerals, is considered as the source of arsenic [2].

Arsenic pollution of groundwater in Ganges River basin, West Bengal, India, and Bangladesh is known for long. The detection of the arsenic pollution is in 1982 and 1993, respectively. The investigations and countermeasures have been performed [3-6].

On the other hand, in Mekong River basin, Vietnam, Cambodia and Laos, arsenic pollution was first confirmed around 2000 and countermeasures just began under help such as UNICEF and GIST (Gwangju Institute

"Corresponding author. of Science and Technology) $[7,8]$.

The authors have elucidated the mechanism for arsenic contamination and developed the safe water devices in Bangladesh since 1997 together with the NGO "Asia Arsenic Network" (AAN) [9]. AAN has implemented the Arsenic Mitigation Project with Japan International Cooperation Agency (JICA) in Bangladesh from 1999 until now. The University of Miyazaki has conducted activities for arsenic mitigation in Uttar Pradesh State, India, under a JICA technical cooperation project from 2008 until now, in collaboration with AAN.

Uttar Pradesh State (abbreviated as UP State hereafter) is located at north of India bordering on Nepal, Geographical area of which is about $4700 \mathrm{~km}^{2}$, where two big rivers are running from the northwest to the southeast. The former is the Ghaghara River flowing down from the arsenic affected Terrai plane, and the latter is the Ganges River as shown in Figure 1. The arsenic contamination in UP State was first recognized in 2003 at Ballia District, where both of the Ghaghara and the Ganges are joining. 


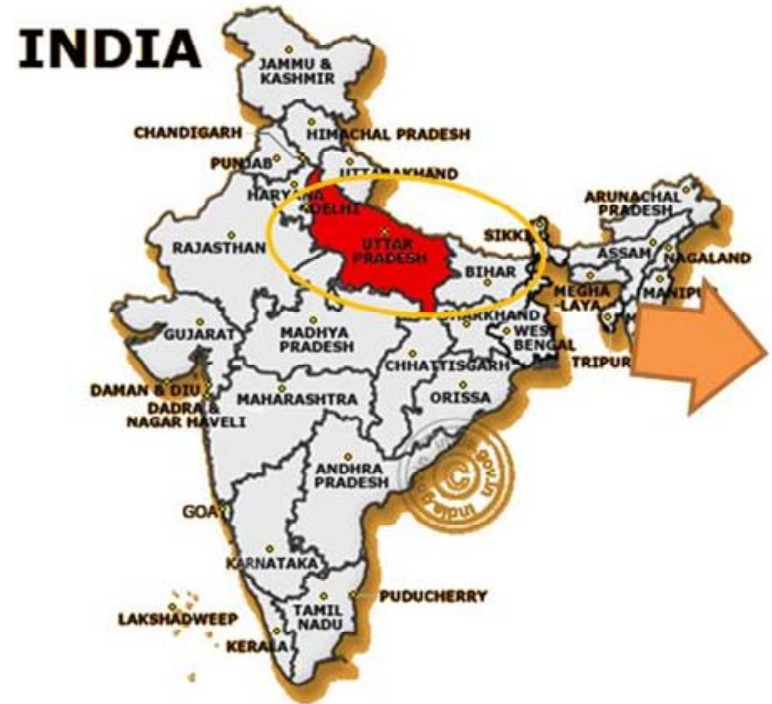

(a)

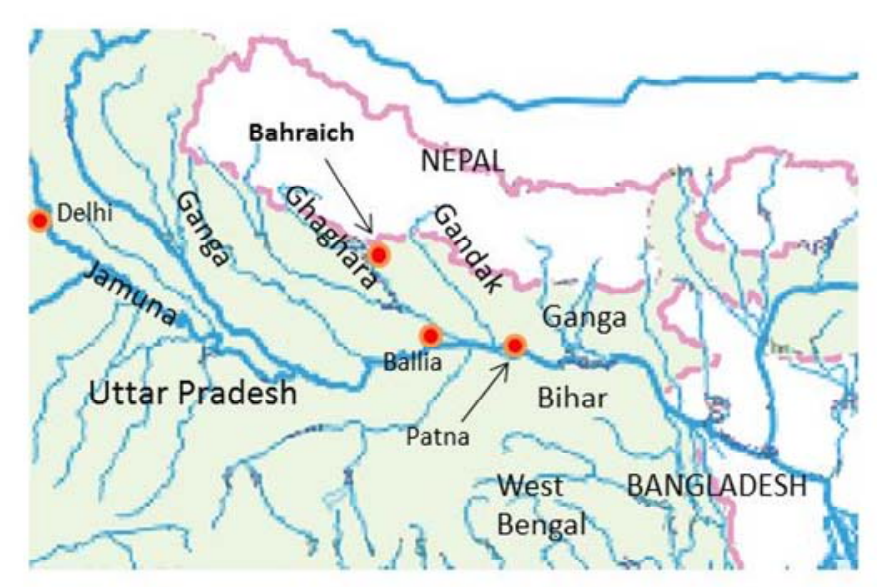

(b)

Figure 1. (a) Location of Uttar Pradesh; (b) Location of project area, Bahraich district.

Arsenic-contaminated tubewell water is detected in the 20 Districts out of 70 Districts in UP State by UP government under the assistance of UNICEF. The government survey was, however, performed only for the government tubewells (GTWs), and private tubewells (PTWs), numerous compared with GTW, were not checked at all. In regard to arsenocosis patients, the number of patient is unknown yet, because the medical examination has not been executed until now.

Our project area is in Bahraich District (See Figure 1(b)), severely arsenic affected one in the above-mentioned 20 Districts. The project is an integrated arsenic mitigation with 3 activities: 1) Raising awareness of villagers for poison of arsenic through a street play, etc.; 2) Identification of arsenocosis patients after training local medical doctors for diagnosis of chronic arsenic poisoning; 3) Installation of arsenic removal unit after checking all tubewells used in the villages.

Though the groundwater of the Ganges medium basin is contaminated with arsenic, few reports [10-12] are obtained. We will, therefore, introduce the situation and mechanism of arsenic contamination of groundwater, obtained from the $1^{\text {st }}$ phase of JICA arsenic mitigation project (2008-2011) as an interim report.

This paper mainly shows the data obtained in the activity (3) mentioned above.

\section{Situations of Arsenic Contamination in UP State}

Figure 2 shows the ratio of arsenic polluted GTW (As > $50 \mathrm{ppb}$ ) in the 20 Districts obtained from the above mentioned government survey. There are 3 severe con taminated Districts: Kehri, Ballia, and Bahraich. The detection of arsenic contamination in Kehri was right after that in Ballia, and 500 of deep wells were installed in Ballia and

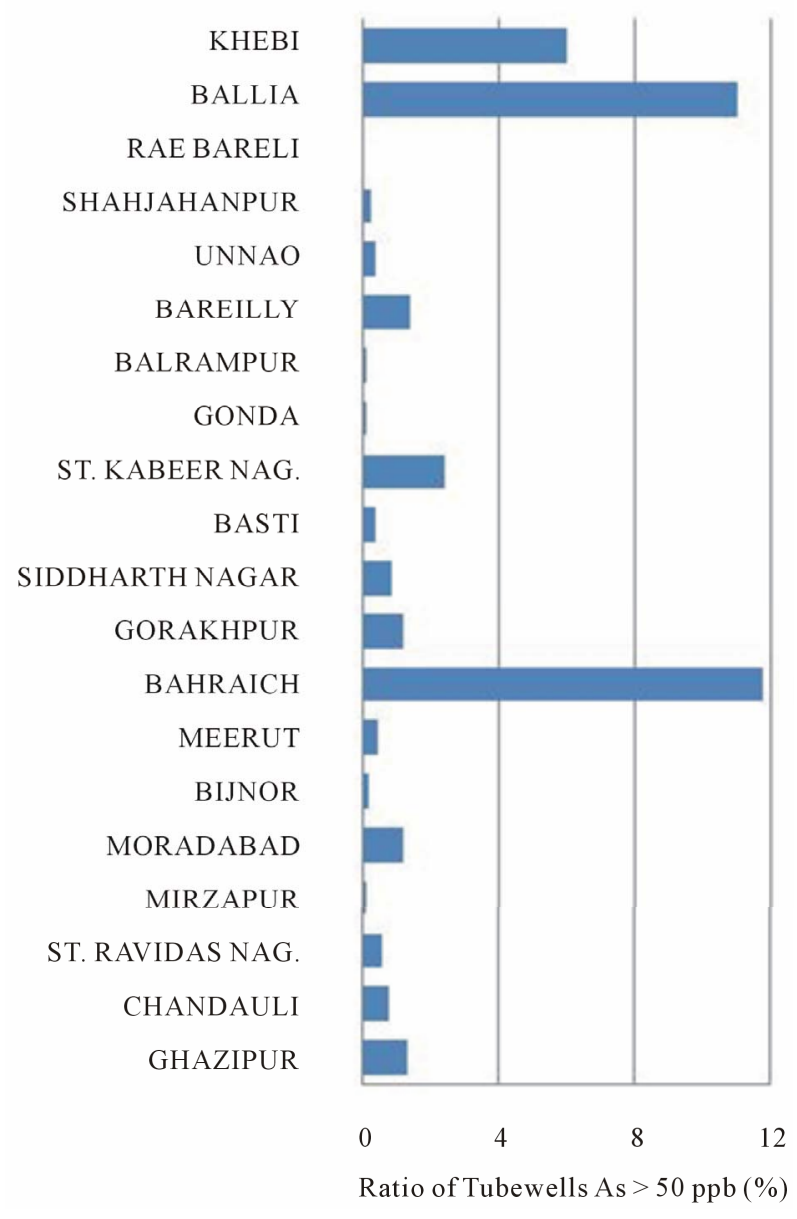

Figure 2. Ratio of As $>50$ ppb TWs in Districts of UP State. 
250 wells in Kehri.

The ratio of arsenic contaminated GTWs is highest in Bahraich District, where we have been performed the JICA project. The project area belongs to Tejwapur Block in Bahraich District, which is composed of 14 Blocks. The arsenic contamination is seen in the 10 out of 14 Blocks. Figure 3 shows the ratio of GTW of As > $50 \mathrm{ppb}$ in the 10 Blocks. It is clear that the arsenic contamination is highest in the Tejwapur Block.

Tejwapur Block has 80 villages. In 9 out of 80 villages, GTW of As $>50 \mathrm{ppb}$ is detected. Figure 4 shows the situations of arsenic contamination in the 9 villages. The ratio of As $>100 \mathrm{ppb}$ is highest in Newada village, followed by Chetra village. The JICA project area is in the both villages with 4 habitations in Newada village and 3 habitations in Chetra village.

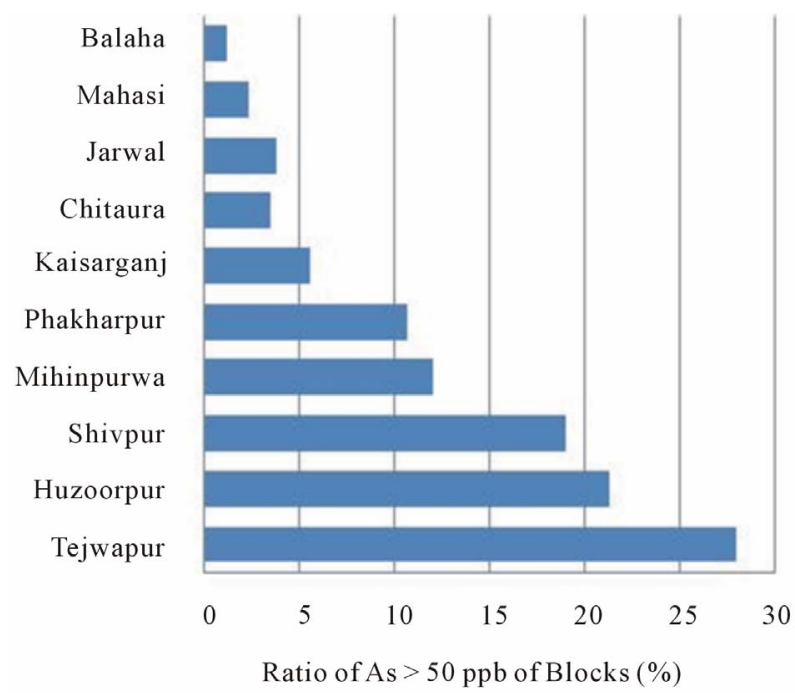

Figure 3. Ratio of As affected TW in Blocks of Bahraich District.

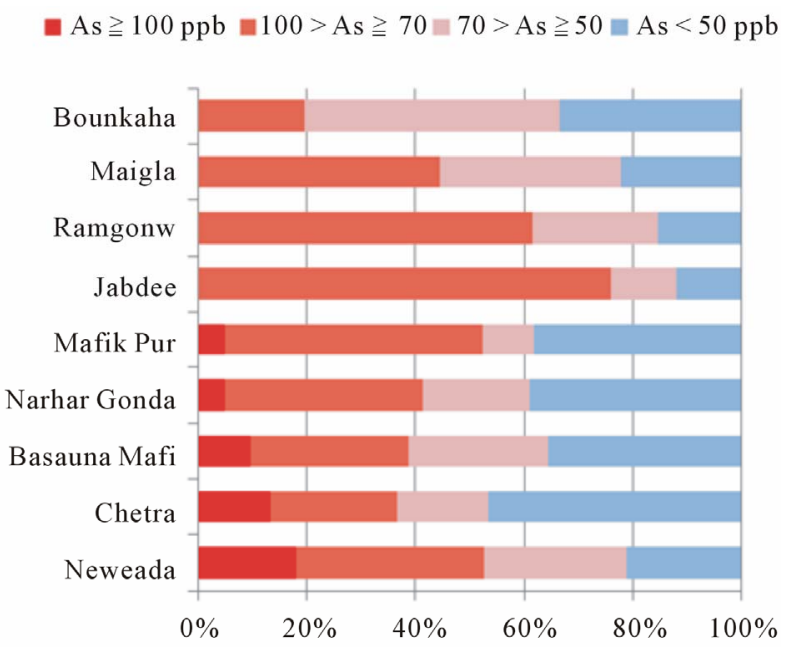

Figure 4. Ratio of TW of As $>50 \mathrm{ppb}$ in the 9 villages of Tejwapur Block.

\section{Arsenic Contamination of Groundwater in the Project Area}

\subsection{Arsenic Contamination of Groundwater}

We had measured the arsenic concentration of all tubewells in the project area, which is composed of 7 habitations. The number of tubewells in the 7 habitations is 42 of GTW and 323 of PTW. The arsenic concentration measured is shown in Figures 5(a) and (b).

GTWs (Depth: about $30 \mathrm{~m}$ ) are almost contaminated with arsenic, in which $62 \%$ of TW shows As $>50 \mathrm{ppb}$ and $98 \%$ for As $>10 \mathrm{ppb}$ on the average in the seven habitations. The highest contamination is seen in Newada Proper and the lowest in Chetra Proper.

On the other hand, the arsenic contamination in PTW

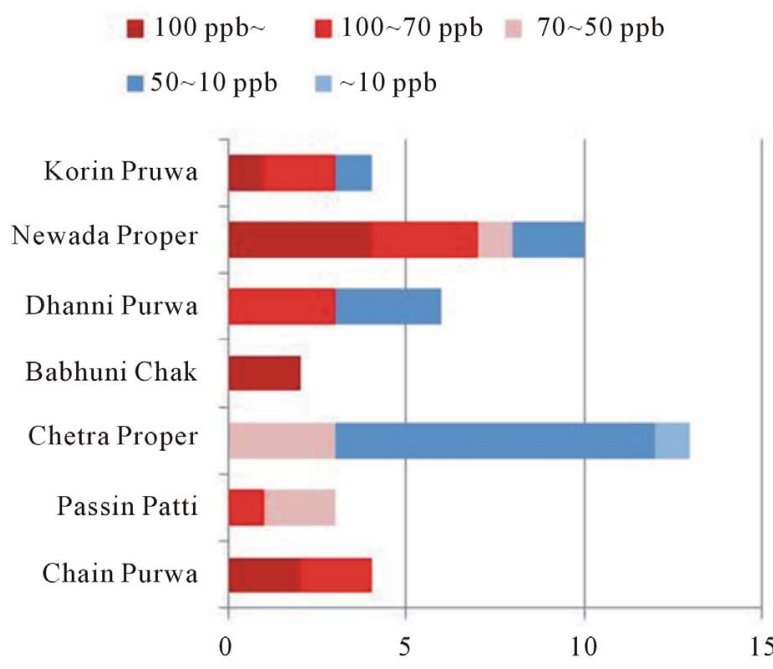

(a)

$$
\begin{aligned}
& \square 100 \mathrm{ppb} \quad 100 \sim 70 \mathrm{ppb}=70 \sim 50 \mathrm{ppb} \\
& \square 50 \sim 10 \mathrm{ppb} \square \sim 10 \mathrm{ppb}
\end{aligned}
$$

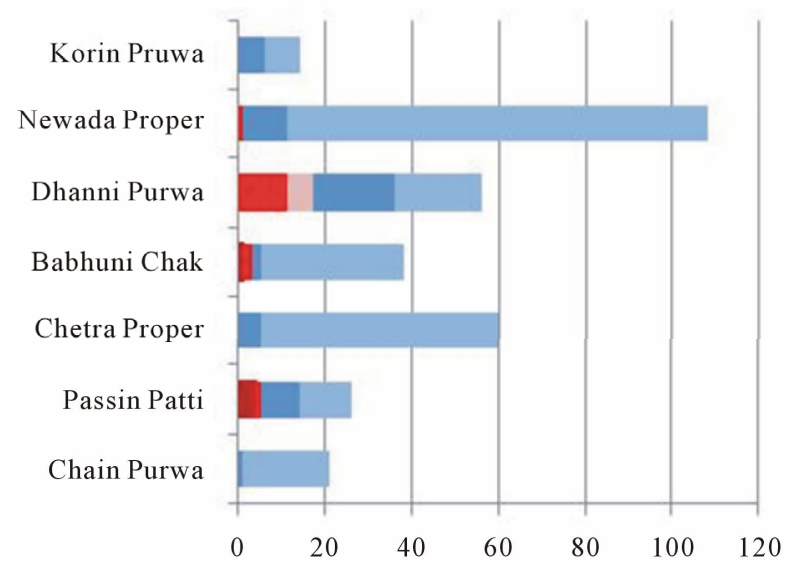

(b)

Figure 5. (a) As concentrations of government TWs in habitation (total number: 42); (b) As concentrations of private TWs in habitation (total number: 323 ). 
(Depth: about $10 \mathrm{~m}$ ) is overall low. PTW of As $>50 \mathrm{ppb}$ is $8 \%$ and $24 \%$ for As $>10 \mathrm{ppb}$ on the average in the seven habitations. The high arsenic contamination is, however, seen in Passin Patti and Babhuni Chak, which should be remarkable.

\subsection{Mechanism of Arsenic Release}

We had examined water quality for 11 GTWs an 12 PTWs. A part of the results is shown in Figures 6(a) and (b). The symbols in the figures are explained in Table 1. From these figures, it is understood that most of arsenic-safe water in PTWs is in oxidized conditions because of positive values of ORP and little of $\mathrm{Fe}^{2+}$. And, PTW is dirtier than GTW with much dissolved ions from high EC.

Figure 7 shows the relation of total arsenic concentration and total iron concentration in the GTW ( $\square)$ \& PTW (०). The concentration between As and Fe shows a liner relation with some scattered data in the both tubewells.

The arsenic valence in the arsenic contaminated GTWs \& PTWs was all trivalent, As(III), which shows the reduced condition in groundwater.

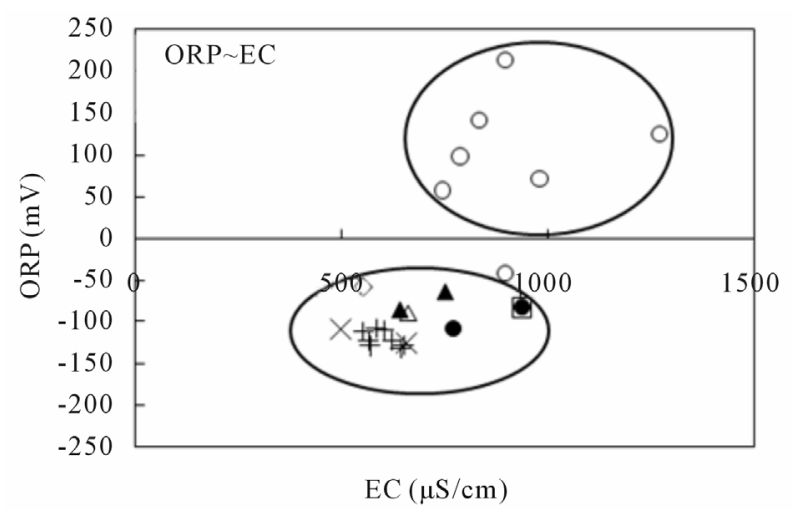

(a)

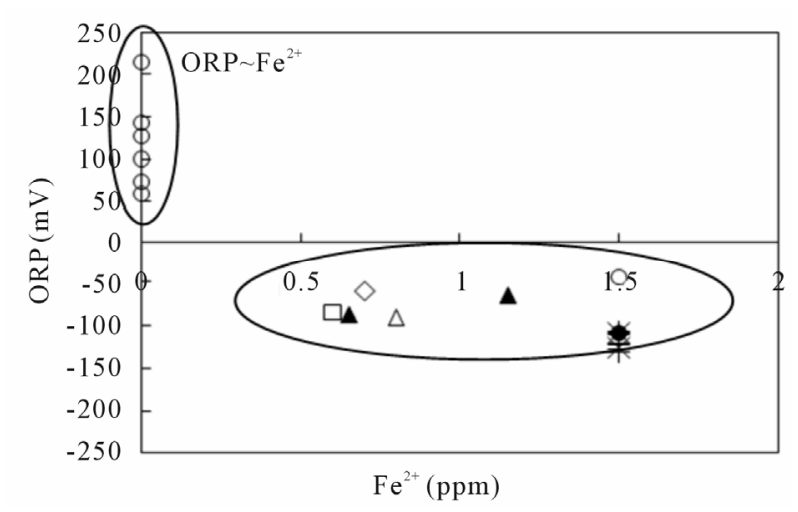

(b)

Figure 6. Relation between PTW without As and GTW with As.
Table 1. Arsenic concentration in Figure 6 (mg/L).

\begin{tabular}{ccc}
\hline & $\times$ & $0.1 \leqq \mathrm{AS}$ \\
$\mathrm{GTW}$ & + & $0.05 \leqq \mathrm{AS}<0.1$ \\
& $\diamond$ & $0.01 \leqq \mathrm{AS}<0.05$ \\
\hline & $\Delta$ & $0.1 \leqq \mathrm{AS}$ \\
$\mathrm{PTW}$ & $\bullet$ & $0.05 \leqq \mathrm{AS}<0.1$ \\
& $\square$ & $0.01 \leqq \mathrm{AS}<0.05$ \\
& $\triangle$ & $0 \leqq \mathrm{AS}<0.01$ \\
& $\circ$ & $\mathrm{AS}=0$ \\
\hline
\end{tabular}

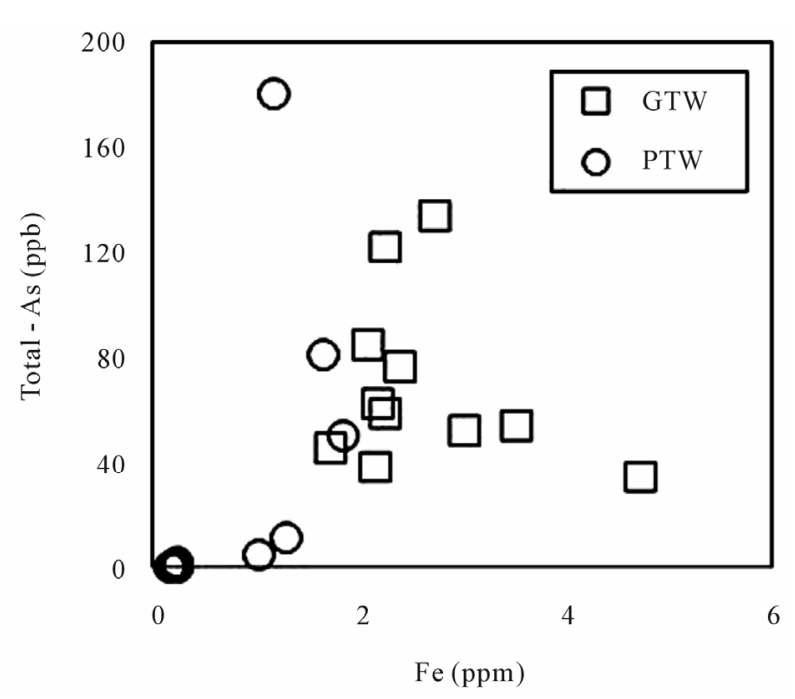

Figure 7. Relation between concentration of As and Iron.

From these data, we consider that arsenic, which had been absorbed with iron in underground, was released into groundwater under the reduced conditions.

\subsection{Relation between Arsenic and Nitrogen}

We found roughly a linear correlation between concentrations of arsenic and ammonia in the above data. So, we collected more samples to check the correlation.

Figure 8 shows the $\mathrm{NH}_{4}^{+}-\mathrm{N}$ exits in both shallow tubewell (PTW) and deep tubewell (GTW). It may be considered the source of nitrogen is from cow dung on the garden or fertilizer in the cultivated field. The concentration of $\mathrm{NH}_{4}^{+}-\mathrm{N}$ shows fairly a linear correlation with that of arsenic from Figure 9. It may be considered that influences of microorganism activities on arsenic release under the reduced conditions, which will be a research theme in future.

\section{Arsenic Content in Underground}

We had test borings, showing the geological profiles with the alternation of fine and medium sand until $80 \mathrm{~m}$ depth 


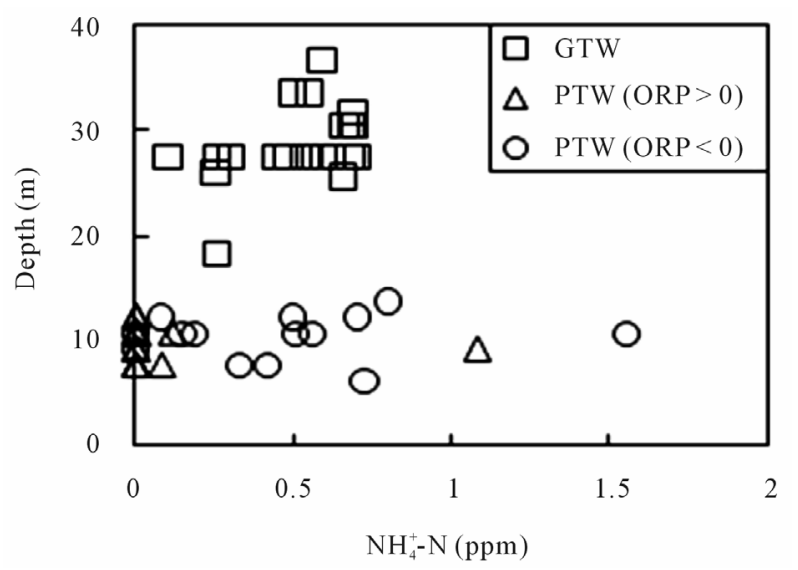

Figure 8. $\mathrm{NH}_{4}^{+}-\mathrm{N}$ detected both PTW and GTW.

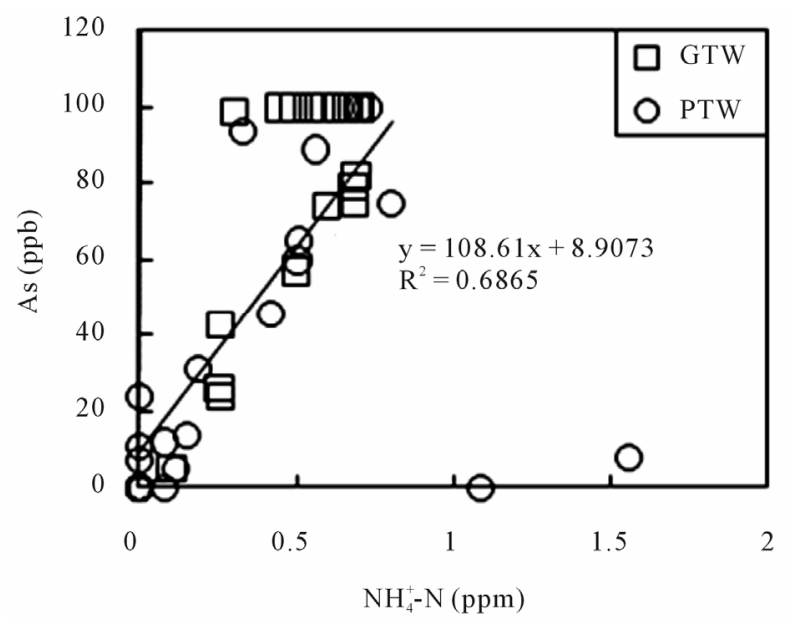

Figure 9. Correlation of $\mathrm{NH}_{4}^{+}-\mathrm{N}$ with As.

without any silt and clay layers. Figure $\mathbf{1 0}$ shows the distributions of arsenic and iron contents along to soil depth until $30 \mathrm{~m}$, in which the boring was performed near to the arsenic contaminated GTW (depth: about $30 \mathrm{~m}$ ).

From Figure $\mathbf{1 0}$ it is seen that arsenic concentration is harmony with that of iron and high arsenic contents exits near the depth of $25 \mathrm{~m}$. The modified BCR sequential extraction procedure [13] was applied to get the chemical combining form of arsenic in soil of the boring sample at the $25 \mathrm{~m}$ depth. We used 4 steps of sequential extraction to estimate 1) Water soluble fraction, 2) Exchangeable \& weak acid soluble fraction, 3) Reducible fraction, and 4) Oxidizable fraction. From Figure 11 it may be said that 1) Arsenic has the highest extractability in the step 3, meaning arsenic mainly exits in the oxidized form with iron, aluminum and manganese, 2) There is no arsenic with sulfide as pyrite because no arsenic extraction in the step 4, and 3) It may be estimated that arsenic exits with carbonate from step 2 (Extraction of arsenic with calcium in step 4), because of much calcareous soil (Kankar) in UP State [14].

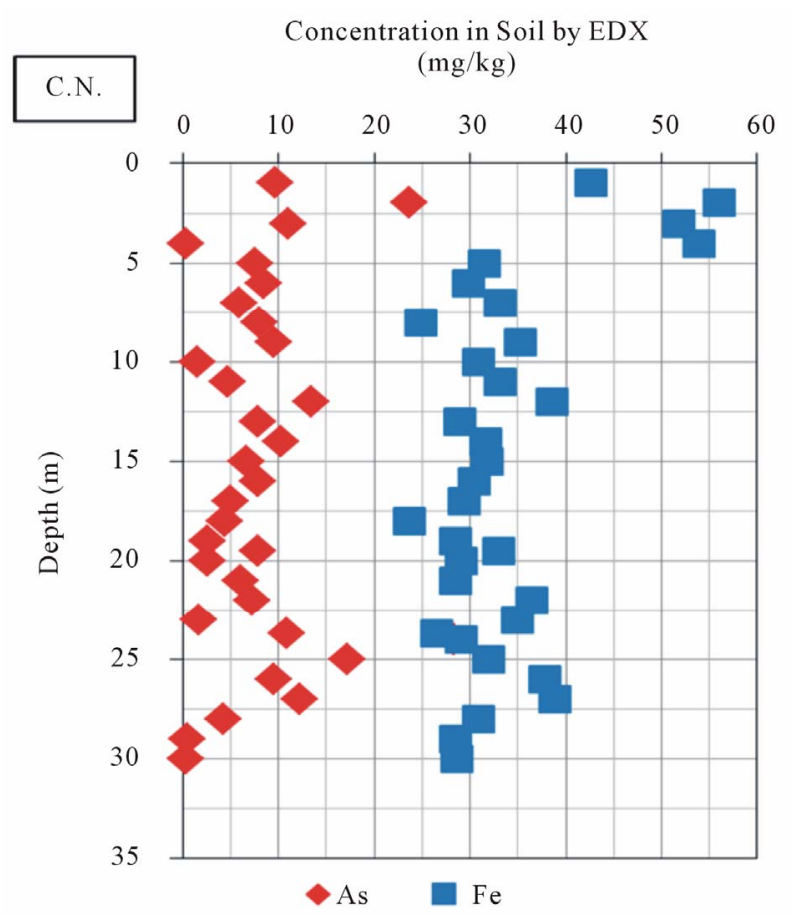

Figure 10. Contents of Arsenic and Iron in underground.

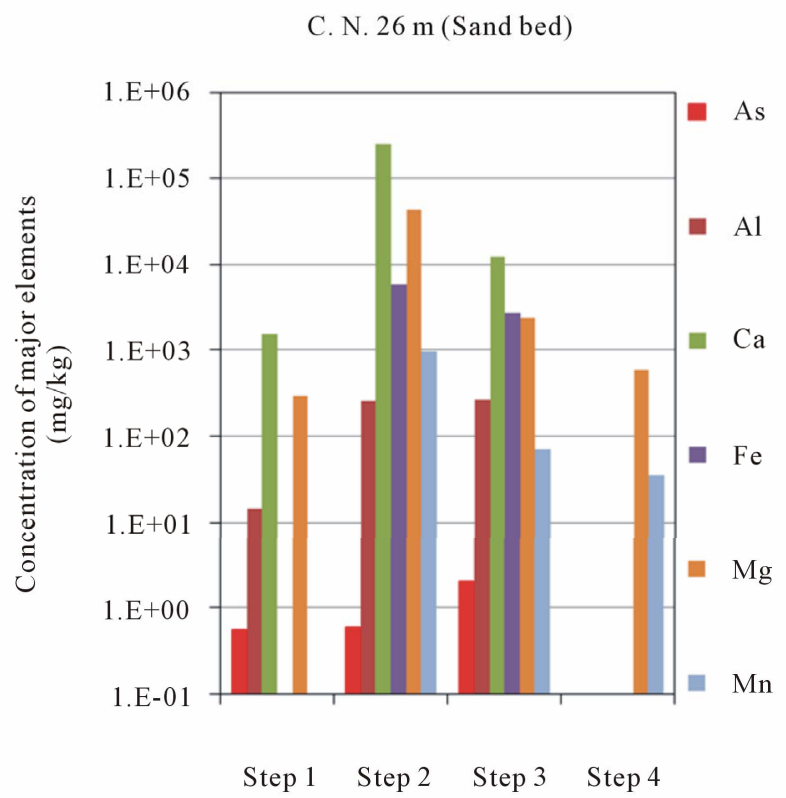

Figure 11. Contents of Arsenic and Iron in underground.

\section{Arsenic Release Mechanism}

From the results in the above 4 and 5, it may be said that arsenic, mainly fixed in Fe- and/or Mn-oxides in the underground, was released to groundwater under the reduced condition through microorganism activities with the existence of nitrogen acting on the metabolism of microorganism. It is similar mechanism in Bangladesh [15], although there is different in soil profile, abundant 
clay in Bangladesh and no clay in our project area, UP State.

\section{Alternative Water Supply System and Arsenocosis Patients}

In the project we installed 10 units of alternative water supply: 3 filters for dugwells to treat the Fecal coliform bacteria and 7 arsenic removal plants, GSF, for government tubewells to remove arsenic.

GSF (Gravel Sand Filter) is a community-based arsenic removal unit, removing arsenic by co-precipitating of arsenic with iron in the gravel tank after aeration of groundwater. GSF has been developed by us [16], and more than 50 GSFs are now operated at the arsenic affected villages in Bangladesh.

750 out of 3000 villagers had drunk arsenic-affected tubewell water (As $>50 \mathrm{ppb}$ ) in the project area. We had the medical examinations for detecting the arsenocosis patients together with training local doctors, from which 64 patients were identified. As their symptoms of chronic arsenic poisoning were very mild, they will be improved through drinking the arsenic safe water.

\section{Conclusions}

In this paper, the following results are obtained.

1) The government tubewells (depth: $30 \mathrm{~m}$ ) are almost contaminated with arsenic and the private tubewells (depth: $10 \mathrm{~m}$ ) are overall not affected with arsenic.

2) The arsenic contaminated tubewells are under reduced condition and the non-arsenic tubewells are under the oxidized condition, meaning that arsenic is leached out into groundwater under reduced condition.

3) Arsenic concentration has roughly linear correlation with those of iron and ammonia in the groundwater.

4) Ground is composed of sand until $80 \mathrm{~m}$ with high arsenic content at around $25 \mathrm{~m}$ depth, where similar release mechanism as Bangladesh might be considered, although there is different in soil profile: abundant clay layer in Bangladesh and no clay in the project area, UP State.

5) 750 out of 3000 villagers had drunk the arsenic contaminated water, and 64 of arsenocosis patients have been identified.

\section{REFERENCES}

[1] H. Yokota, "Arsenic Pollutions of Groundwater in the World and Arsenic Removal Unit Installed in Bangladesh," Keynote Lecture, Vietnam-Japan Joint Seminar on Geotechnics and Geoenvironment Engineering, Hanoi, November 2004, pp. 226-242.

[2] R. B. Sah, "Studies for Possible Natural Sources of Arsenic Poisoning of Groundwater in Terai Plain of Nepal," Arsenic Research Committee, Department of Geology,
Tribhuvan University, 2002.

[3] D. Chakraborty, G. Samanta, et al., "Arsenic in Ground Water in Six districts of West Bengal, India: biggest arsenic calamity in the world," Environmental Geochemistry and Health, Vol. 18, 1996, pp. 5-15.

[4] M. Feroze Ahmed and C. M. Ahmed, "Arsenic Mitigation in Bangladesh," An Outcome of the International Workshop, Local Government Division, Ministry of LGRD \& Co-Operatives, September 2002.

[5] D. Chakraborti, M. K. Sengupta, M. M. Rahman, S. Ahamed, U. K. Chowdhury, M. A. Hossain, et al., "Groundwater Arsenic Contamination and Its Health Effects in the Ganga-Meghna-Brahmaputra Plain," Journal of Environmental Monitoring, Vol. 6, 2004, pp. 75N-83N.

[6] Ministry of Local Government (Bangladesh) and JICA, "Sustainable Arsenic Mitigation under Integrated Local Government System in Jessore," Final Report, 2008.

[7] K.-W. Kim, P. Chanpiwat, H. T. Hanh, K. Phan and S. Sthiannopkao, "Arsenic Geochemistry of Groundwater in Southeast Asia," Frontiers of Medicine, Vol. 5, No. 4, 2011, pp. 420-433.

[8] K. H. Cho, S. Sthiannopkao, Y. A. Pachepsky, K.-W. Kim and J. H. Kim, "Prediction of Contamination Potential of Groundwater Arsenic in Cambodia, Laos, and Thailand Using Artificial Neural Network," Water Research, Vol. 45, No. 17, 2011, pp. 5535-5544. doi:10.1016/j.watres.2011.08.010

[9] H. Yokota, et al., "Collaboration between NGO and University of Miyazaki and Asian Arsenic Network for the Mitigation of Arsenic Contamination in Ganges Basin," Proceedings of 1st International Symposium on Health Hazards of Arsenic Contamination of Groundwater and Its Countermeasures, Keynote Lecture, 2006, pp. 47-58.

[10] S. Ahamed, M. Kumar Sengupta, B. Das, B. Nayak, A. Pal, A. Mukherjee, M. Amir Hossain and D. Chakraborti, "Arsenic Groundwater Contamination and Its Health Effects in the State of Uttar Pradesh (UP) in Upper and Middle Ganga Plain, India: A Severe Danger," Science of the Total Environment, Vol. 370, No. 2-3, 2006, pp. 310322. doi:10.1016/i.scitotenv.2006.06.015

[11] A. K. Srivastava and R. M. Tripathi, "Arsenic in Ground Water in Uttar Pradesh: Testing and Mitigation Activities," Proceedings of 1st International Symposium on Health Hazards of Arsenic Contamination of Groundwater and its Countermeasures, 2006, pp. 77-82.

[12] Y. Yano, A. Kodama, K. Shiomori, M. Sezaki, K. Tanabe, R. Jaiswal, P. Jaiswal, Tripathi and H. Yokota, "Arsenic Contamination of Groundwater at Uttar Pradesh State in India," International Symposium on Geo-disaster Prevention and Geo-environment in Asia, JS-Fukuoka, The Japanese Geotechnical Society, 2009, pp. 193-198.

[13] M. Pueyo, J. Sastre, E. Hernandez, M. Vidal, J. F. LopezSanchez and G. Rauret, "Predection of Trace Element Mobility in Contaminated Soils by Sequential Extraction," Journal of Environmental Quality, Vol. 32, No. 6, 2003, pp. 2054-2066. doi:10.2134/jeq2003.2054

[14] National Environmental Engineering Research Institute, Nagpur, "Assessment of Generation, Treatment, Disposal 
and Selection of Disposal Sites for Hazardous Wastes in Kanpur," Uttar Pradesh Pollution Control Board, Lucknow, 1996, pp. 102-112.

[15] J. Akai, K. Izumi, H. Fukuhara, H. Masuda, S. Nakano, T. Yoshimura, H. Ohfuji, Md. Anawar Hossain and K. Akai, "Mineralogical and Geomicrobiological Investigations on Groundwater Arsenic Enrichment in Bangladesh," Ap- plied Geochemistry, Vol. 19, No. 2, 2004, pp. 215-230. doi:10.1016/j.apgeochem.2003.09.008

[16] M. Hussainuzzaman and H. Yokota, "Efficiency of Arsenic Removal Unit working in Bangladesh and Cement Stabilization of Its Sludge," Journal of ASTM International, Vol. 3, No. 4, 2006, pp. 1-9. 